\title{
IN VITRO AND IN VIVO ACTIVITY OF HOMEOPATHIC DRUGS AGAINST BOVINE HERPESVIRUS-1 AND BOVINE VIRAL DIARRHOEA VIRUS 1
}

\author{
A. V. NEFEDCHENKO, T. I. GLOTOVA \& A. G. GLOTOV \\ Institute of Experimental Veterinary Medicine of Siberia and Far East of the Russian \\ Academy of Agricultural Sciences, Novosibirsk, Russian Federation
}

\begin{abstract}
Summary
Nefedchenko, A. V., T. I. Glotova \& A. G. Glotov, 2015. In vitro and in vivo activity of homeopathic drugs against bovine herpesvirus-1 and bovine viral diarrhoea virus 1. Bulg. $J$. Vet. Med., 18, No 1, 56-64.

The goal of this work was to study an in vitro and in vivo activity of combination homeopathic remedies against the BHV-1 and BVDV-1 viruses. To do so, we determined the antiviral activity of Euphorbium compositum Nasentropfen S, Engystol, and Echinacea compositum SN in cell cultures by measuring the drop in the concentration of these viruses. The in vivo experiment was conducted in 10 seronegative calves aged 2 to 3 months. The live Trivac vaccine was administered intranasally to all calves. For 10 days, the animals received subcutaneous injections of Engystol in the study group and of normal saline in the control group. The concentration of the viruses and the duration of their excretion with nasal discharge, as well as the titres of antiviral antibodies were determined. The in vitro tests showed that all studied remedies exhibited antiviral activity to varying degrees. In the in vivo experiment, Engystol reduced the concentration of the viruses and the duration of their excretion with the calves' nasal discharge, having no effect on the production of antiviral antibodies.
\end{abstract}

Key words: antiviral activity, cattle, bovine herpesvirus-1 and bovine viral diarrhoea virus 1 , homeopathy

\section{INTRODUCTION}

Respiratory diseases of young cattle are one of the major causes of economic losses in beef and dairy cattle husbandry. They lead to mortality or growth stunt in affected animals and incur additional costs for treatment, diagnostics, and preventive procedures (Griffin, 1997). These diseases are multifactorial and polyetiological.
Homeopathic remedies were initially developed for human medicine and well after that they were introduced in the veterinary practice (Kaiser, 1989). The available literature reports a successful use of homeopathic remedies for treatment and prevention of postpartum conditions, mastitis, and ovarian dysfunction in cows and enteritidis in calves (Clausena, 2013). 
Some authors reported experiments in which they treated respiratory diseases of calves caused by the bovine parainfluenza virus type-3 (BPIV-3) with combination homeopathic remedies (Grandel, 1976; Kovacs \& Gubanowa, 2000). They evaluated the efficacy of homeopathic remedies by a change in the clinical presentation of respiratory infections in calves caused by BPIV-3. The results of these studies have not been confirmed by any virology assays that may prove the antiviral activity of the studied remedies.

It is established that the bovine herpesvirus-1 (BHV-1) and the bovine viral diarrhoea virus 1 (BVDV-1) play a leading role in respiratory morbidity of calves in animal farms in the Russian Federation (Glotov et al., 2002). These viruses have a direct and mediated effect on the respiratory system and trigger a mechanism of pathophysiologic changes that lead to the disease (Brogden \& Guthmiller, 2002). In large herds these viruses circulate almost continuously imposing a constant risk of respiratory diseases in calves (Taylor et al., 2010; Glotov et al., 2013).

In vitro experiments showed an antiviral activity of some combination homeopathic remedies against human respiratory viruses (Glatthaar-Saalmüller \& FallierBecker, 2001; Oberbaum et al., 2005; Roeska \& Seilheimer, 2010), but there is no data on similar studies dedicated to cattle respiratory viruses.

To fill this gap, we decided to study an in vitro and in vivo activity of combination homeopathic remedies against BHV1 and BVDV-1. For this study we chose Euphorbium compositum Nasentropfen S, Engystol, and Echinacea compositum SN. These remedies had already been used to treat upper respiratory tract infections in humans and animals (Heel, 2003).

\section{MATERIALS AND METHODS}

Remedies. For the study, we used Euphorbium compositum Nasentropfen S (Euphorbium com.) (batch 17635), Echinacea compositum SN (Echinacea com.) (batch 14859 A), and Engystol (batch 17398 A) from Biologische Heilmittel Heel (BadenBaden, Germany). As a reference drug we used Phosprenyl (a $0.4 \%$ solution of polyprenyl phosphates) (batch 1056-1058) from ZAO "Micro-plus" at the Gamalea Epidemiology Research Institute of the Russian Academy of Medical Sciences.

Cell culture and viruses. The strains of BHV-1 (TK-A (AREVRI) B-2 strain) and BVDV-1 (VK-1(B-1) N 28 strain) were obtained from the Kovalenko All-Russian Experimental Veterinary Research Institute (AREVRI, Moscow, Russia). The viruses were passaged in cell cultures (BHV-1 in a MDBK culture and BVDV-1 in a KST culture) in Eagle's MEM medium with foetal serum, 5-10\% (Perbio HyClone, USA), L-glutamine, $0.06 \%$, and kanamycin, $100 \mu \mathrm{g} / \mathrm{mL}$.

Determination of virus titre. The concentration of the BHV-1 and BVDV-1 viruses was determined in MDBK and KST cell cultures respectively by cytopathic effects on day 5-7 according to the standard method. The titre of the viruses was calculated as per Reed \& Muench (1938), expressed in median tissue culture infective dose and converted to logarithmic units $\left(\log _{10} \mathrm{TCID}_{50} / \mathrm{mL}\right)$.

Determination of the cytotoxicity of the remedies. The cytotoxicity of the studied remedies was determined in 48-hour MDBK and KST cell cultures by cell viability. To do so, the studied remedies were added to the cell cultures in concentrations of $50,100,200$, and $500 \mu \mathrm{L} / \mathrm{mL}$ and incubated for 4 days. The viability of the cells was evaluated after staining with a trypan blue solution $(10 \mathrm{mg} / \mathrm{mL}$ in a 
phosphate buffer), and the $50 \%$ cytotoxic concentration $\left(\mathrm{CC}_{50}\right)$ was calculated. All tests were repeated 3 times (Kinchington \& Schinazi, 2000).

Antiviral effects of the remedies. The assays were performed in 96-well culture plates. A 48-hour cell monolayer was used. The BHV-1 and BVDV-1 viruses were added in a concentration of 1 $\mathrm{TCID}_{50} / 100 \mu \mathrm{L}$ of medium, the homeopathic remedies were added in a concentration of $100 \mu \mathrm{L} / \mathrm{mL}$ of medium, and Phosprenyl was added in a concentration of $200 \mu \mathrm{g} / \mathrm{mL}$ of medium. The wells that were infected with a virus, but to which no drug was added served as a control.

The experiments were conducted as followed:

- Experiment 1. One hundred $\mu \mathrm{L}$ of a studied agent were added to the cell culture and incubated for 2 hours at $37{ }^{\circ} \mathrm{C}$. Then, the agent was removed, the culture was washed with medium, and a tested virus was introduced.

- Experiment 2. A studied agent was mixed with a tested virus, incubated for 2 hours at $37{ }^{\circ} \mathrm{C}$, and added to the cell culture.

- Experiment 3. A tested virus was added to the cell culture, incubated for 1 hour at $37{ }^{\circ} \mathrm{C}$. Then, the virus was removed, the culture was washed with medium, and $100 \mu \mathrm{L}$ of a studied agent were added.

After a 72-hour incubation, the titre of the virus was determined (Habriev, 2005).

Design of the in vivo experiment. Ten clinically healthy calves of the Holstein breed, 2 to 3 months of age, were placed in separate cages in an isolated stall on the farm. During the adaptation period (2 weeks) and the experiment itself, the animals were on a standard diet. From all animals blood samples were obtained, and serum was tested for antibodies against
BHV-1 and BVDV-1 in a virus neutralization test. All animals were initially seronegative to the studied viruses.

Subsequently, the animals were randomly divided into test $(\mathrm{n}=5)$ and control $(n=5)$ groups. On the zero day of the experiment each animal from the test and control groups received as aerosol in each naris $1 \mathrm{~mL}$ of Trivac (AREVRI) vaccine containing attenuated strains of the BHV1, BVDV-1, and BPIV-3 viruses: the BHV-1 "TK-A (AREVRI) B-2" strain in concentrations of $10^{4.5}-10^{6.5} \mathrm{TCID}_{50} / \mathrm{mL}$, the BVDV-1 "VK-1(B-1) N 28" strain in concentrations of $10^{4.0}-10^{6.0} \mathrm{TCID}_{50 / \mathrm{mL}} \mathrm{m}$, and the BPIV-3 "PTK-45/86" strain in concentrations of $10^{5.0}-10^{7.0} \mathrm{TCID}_{50} / \mathrm{mL}$.

From day 0 to day 10, Engystol $2 \mathrm{~mL}$ QD was administered subcutaneously to all animals from the test group. The control animals received normal saline instead. The calves were observed for 21 days after the inoculation of the vaccine.

Nasal swabs were collected from all calves on days $0-7,14$, and 21 after the inoculation of the vaccine to determine the titre of the viruses. On day 0 and 21 blood serum samples were obtained to determine the titre of antiviral antibodies.

From the test and control calves $50 \mathrm{se}$ rum samples and 100 nasal swabs were collected. All collected biological samples were labelled, frozen, and stored at minus $70{ }^{\circ} \mathrm{C}$ until the test.

Before the test, the nasal swabs were resuspended in $1 \mathrm{~mL}$ of Eagle's MEM medium, filtered through a membrane filter (Syringe Filters), and then the virus titer was determined as described above.

Serologic assays. Before the test, the serum samples were warmed up for 30 min at $56{ }^{\circ} \mathrm{C}$. The antiviral antibody titres in the sera collected from the test and control animals were evaluated in a virus neutralization test according to the standard 
method (OIE, 2000a,b). The test was done in MDBK and KST cell cultures using homologous viruses.

Statistical analysis. The received results were tested for significance by Student's $t$-test using Statistica 8 . The differences were considered significant at $\mathrm{P}<0.05$.

\section{RESULTS}

The combination of homeopathic remedies Euphorbium com., Echinacea com., and Engystol at $100 \mu \mathrm{L} / \mathrm{mL}$ exhibited no toxicity to MDBK and KST cell cultures, and therefore this concentration was used to determine the antiviral activity. The control drug Phosprenyl was used at a concentration of $200 \mu \mathrm{g} / \mathrm{mL}$, previously determined by us as the effective concentration (50\%) (Glotov et al., 2004).

Table 1 shows the data on the antiviral activity of the homeopathic remedies. The results of three experiments showed that Engystol more effectively inhibited BHV1 replication (reduction by $36.16 \%$, $73.19 \%$, and $70.55 \%$ ), and that Euphorbium comp. was better at inhibiting

Table 1. Effect of complex homeopathic drugs on production of BHV-1 and BVDV-1 in MDBK and KST cell cultures. Homeopathic drugs were tested at a concentration of $100 \mu \mathrm{L} / \mathrm{mL}$; phosprenil $200 \mu \mathrm{g} / \mathrm{mL}$. Data are presented as $\log _{10} \mathrm{TCID}_{50} / \mathrm{mL}$; mean $\pm \mathrm{SD}(\mathrm{n}=3)$

\begin{tabular}{|c|c|c|c|c|}
\hline & & \multicolumn{3}{|c|}{ Design of drug application } \\
\hline & & $\begin{array}{l}2 \mathrm{~h} \text { before virus } \\
\text { exposure }\end{array}$ & $\begin{array}{l}\text { simultaneously } \\
\text { with virus expo- } \\
\text { sure }\end{array}$ & $\begin{array}{c}2 \mathrm{~h} \text { after virus } \\
\text { exposure }\end{array}$ \\
\hline \multicolumn{5}{|c|}{ BHV-1 } \\
\hline Virus control & virus concentration & $5.67 \pm 0.07$ & $5.67 \pm 0.07$ & $5.67 \pm 0.07$ \\
\hline Engystol & $\begin{array}{l}\text { virus concentration } \\
\% \text { reduction }\end{array}$ & $\begin{array}{c}3.62 \pm 0.07 \\
36.16\end{array}$ & $\begin{array}{l}1.52 \pm 0.18 \\
73.19\end{array}$ & $\begin{array}{c}1.67 \pm 0.07 \\
70.55\end{array}$ \\
\hline $\begin{array}{l}\text { Euphorbium } \\
\text { compositum }\end{array}$ & $\begin{array}{l}\text { virus concentration } \\
\% \text { reduction }\end{array}$ & $\begin{array}{l}4.05 \pm 0.17 \\
28.57\end{array}$ & $\begin{array}{l}2.07 \pm 0.12 \\
63.49\end{array}$ & $\begin{array}{l}2.42 \pm 0.13 \\
56.79\end{array}$ \\
\hline $\begin{array}{l}\text { Echinacea } \\
\text { compositum }\end{array}$ & $\begin{array}{l}\text { virus concentration } \\
\% \text { reduction }\end{array}$ & $\begin{array}{c}4.65 \pm 0.14 \\
17.99\end{array}$ & $\begin{array}{c}4.65 \pm 0.14 \\
17.99\end{array}$ & $\begin{array}{c}4.50 \pm 0.09 \\
20.63\end{array}$ \\
\hline Phosprenyl & $\begin{array}{l}\text { virus concentration } \\
\% \text { reduction }\end{array}$ & $\begin{array}{c}1.34 \pm 0.11 \\
76.37\end{array}$ & $\begin{array}{c}2.00 \pm 0.07 \\
64.72\end{array}$ & $\begin{array}{c}2.20 \pm 0.20 \\
61.19\end{array}$ \\
\hline \multicolumn{5}{|c|}{ BVDV-1 } \\
\hline Virus control & virus concentration & $4.67 \pm 0.18$ & $6.67 \pm 0.07$ & $6.67 \pm 0.07$ \\
\hline Engystol & $\begin{array}{l}\text { virus concentration } \\
\% \text { reduction }\end{array}$ & $\begin{array}{l}3.50 \pm 0.12 \\
25.05\end{array}$ & $\begin{array}{c}4.00 \pm 0.12 \\
40.03\end{array}$ & $\begin{array}{c}4.08 \pm 0.18 \\
38.83\end{array}$ \\
\hline $\begin{array}{l}\text { Euphorbium } \\
\text { compositum }\end{array}$ & $\begin{array}{l}\text { virus concentration } \\
\% \text { reduction }\end{array}$ & $\begin{array}{l}2.92 \pm 0.17 \\
37.04\end{array}$ & $\begin{array}{c}2.42 \pm 0.07 \\
\quad 63.72\end{array}$ & $\begin{array}{l}2.75 \pm 0.12 \\
58.77\end{array}$ \\
\hline $\begin{array}{l}\text { Echinacea } \\
\text { compositum }\end{array}$ & $\begin{array}{l}\text { virus concentration } \\
\% \text { reduction }\end{array}$ & $\begin{array}{c}4.67 \pm 0.07 \\
0\end{array}$ & $\begin{array}{c}5.25 \pm 0.12 \\
21.23\end{array}$ & $\begin{array}{c}4.50 \pm 0.12 \\
32.53\end{array}$ \\
\hline Phosprenyl & $\begin{array}{l}\text { virus concentration } \\
\% \text { reduction }\end{array}$ & $\begin{array}{l}1.74 \pm 0.12 \\
62.74\end{array}$ & $\begin{array}{c}4.00 \pm 0.07 \\
40.03\end{array}$ & $\begin{array}{c}4.19 \pm 0.07 \\
37.18\end{array}$ \\
\hline
\end{tabular}




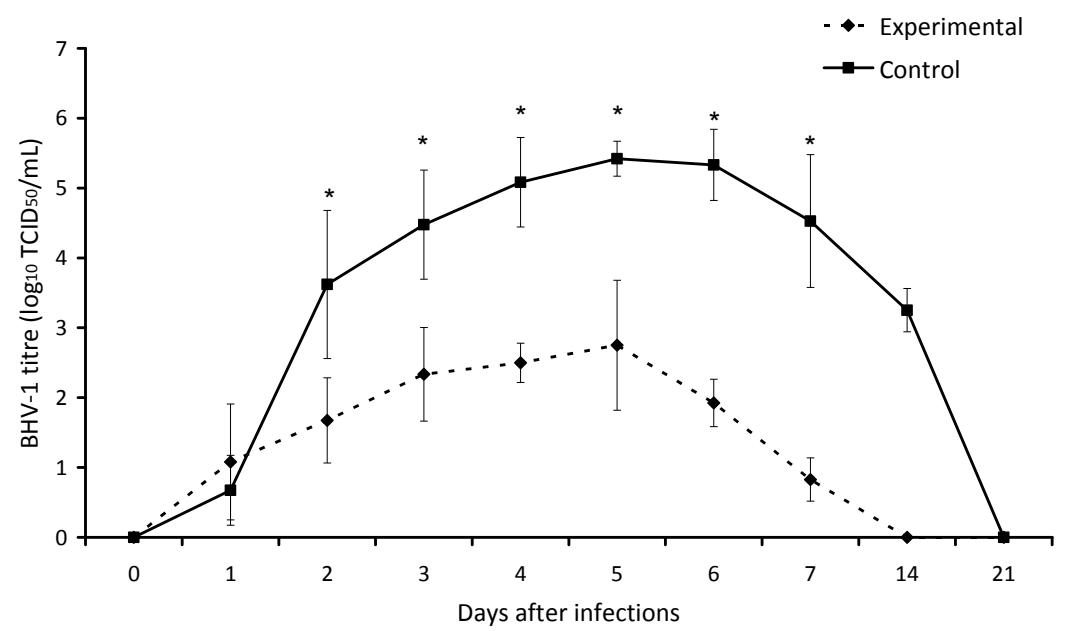

Fig. 1. Infectious activity of BHV-1 in nasal secretions of calves. Data are presented as mean $\pm \mathrm{SD}$ $(\mathrm{n}=5)$. Symbol $(*)$ shows significant differences in similar days between groups $(\mathrm{P}<0.05)$.

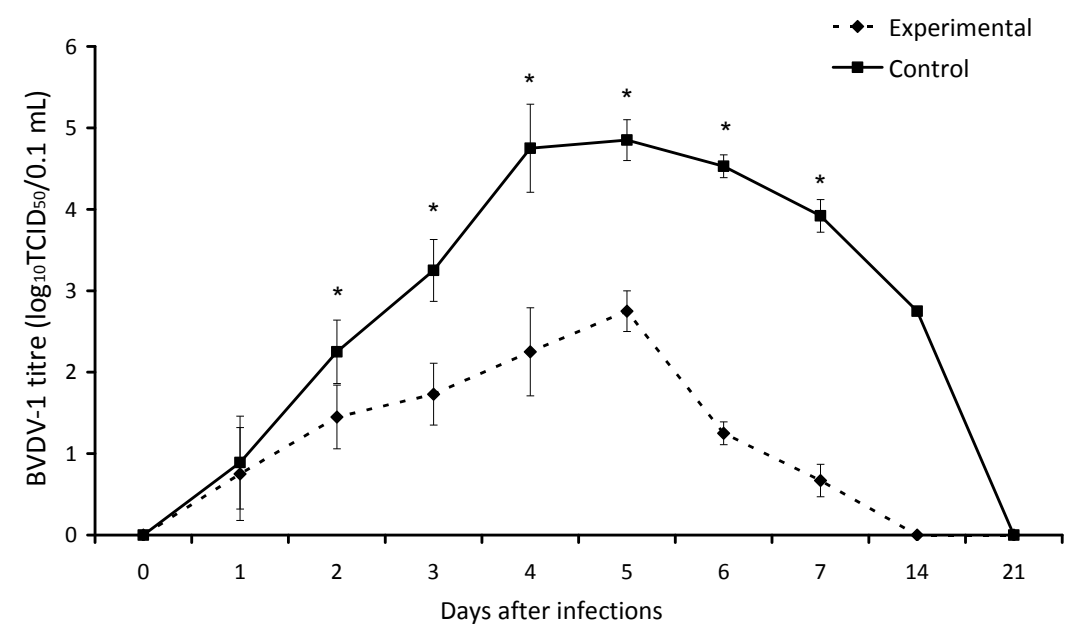

Fig. 2. Infectious activity of BVDV-1 in nasal secretions of calves. Data are presented as mean \pm SD $(\mathrm{n}=5)$. Symbol $(*)$ shows significant differences in similar days between groups $(\mathrm{P}<0.05)$.

BVDV-1 replication (reduction by $37.04 \%$, $63.72 \%$, and $58.77 \%$ ). Notably, the inhibitory effect of both remedies was the highest, if they were added to the cell culture 2 hours after the inoculation of the virus.

Echinacea com. had no effect on BVDV-1 replication in the first experi- ment when the virus was added after 2hour incubation with the remedy. However, it exhibited a high activity in the third experiment. This remedy had low effect on BHV-1 replication.

Fig. 1 and 2, and Table 2 present the effects of Engystol on the infectiousness of the BHV-1 and BVDV-1 viruses in the 
Table 2. Dynamics of serum antiviral antibodies in animals. Data are presented as $\lg _{2}$; mean $\pm \mathrm{SD}$ $(\mathrm{n}=5)$

\begin{tabular}{lcccc}
\hline \multirow{2}{*}{ Groups } & \multicolumn{2}{c}{ BHV-1 } & \multicolumn{2}{c}{ BVDV-1 } \\
& 0 day & 21 day & 0 day & 21 day \\
\hline Experimental & 0 & $3.0 \pm 0.7$ & 0 & $2.7 \pm 0.8$ \\
Control & 0 & $3.4 \pm 0.9$ & 0 & $3.2 \pm 0.8$ \\
\hline
\end{tabular}

calves' nasal discharge, and the titres of antiviral antibodies.

In the test group compared to the control group, a significant $(\mathrm{P}<0.05)$ decrease of the concentration and the duration of excretion of the BHV-1 and BVDV-1 viruses with the calves' nasal discharge was observed.

The infectiousness of the BHV-1 and BVDV-1 viruses in nasal discharge peaked on day 5 after the inoculation, both in the test and the control group. On day 14 after the inoculation, the viruses were detected only in the control group animals.

On day 21 after the vaccination, the level of serum antibodies against BHV-1 and BVDV-1 was higher by $0.4 \log _{2}$ and $0.5 \log _{2}$ respectively in the control group, than in the test group, but these differences were insignificant (Table 2).

\section{DISCUSSION}

With this study, we tried to expand the existing data on the antiviral activity of the combination homeopathic remedies Euphorbium com. and Engystol against the BHV-1 and BVDV-1 viruses, which may cause economic losses in today's animal husbandry. Echinacea com. was included in this study because there is some data of its use for treatment of pneumonias, and despite the absence of any data on its antiviral activity (Anetzhofer, 1993).
As expected, the combination of homeopathic remedies had low toxicity to MDBK and KST cell cultures, but the measures of their toxicity varied. Euphorbium com. caused morphologic changes in the cell monolayer with increased number of dead cells up to $35 \%$ compared to control at $250 \mu \mathrm{L} / \mathrm{mL}$. However Engystol and Echinacea com. exhibited toxicity only at $500 \mu \mathrm{L} / \mathrm{mL}$. This difference may be attributed to a preservative contained in Euphorbium compositum Nasentropfen S. To factor out a dose-dependent effect from the antiviral activity, we used all remedies in the same concentration of 100 $\mu \mathrm{L} / \mathrm{mL}$, which is non-toxic to cell cultures.

As a comparative drug, we chose Phosprenil (a $0.4 \%$ solution of disodium salt of polyprenyl phosphate extracted from Pinus sativum), which has an established antiviral and immunomodulatory effect (Danilov et al., 1996; Pronin et al., 2002).

We detected 3 effects of the studied homeopathic remedies: inhibitory, virucidal, and preventive. A certain dependency between the virucidal and inhibitory effects was observed. The higher is the virucidal effect of the remedy, the deeper is its inhibitory effect.

Authors of previous studies observed a dose-dependent inhibitory effect of Engystol and Euphorbium com. against a broad panel of RNA and DNA viruses with the inhibitory activity decreasing proportionally with the dose down to an 
insignificant level at a concentration of $0.0125 \mu \mathrm{L} / \mathrm{mL}$. One of the mechanisms of the antiviral activity of these remedies may be associated with the direct action on the virus. However, it is impossible that the concentration of a homeopathic remedy in the body will reach the level at which the direct antiviral action occurs.

The data on the preventive effect present a particular interest. This effect of Engystol is higher against BHV-1, and the preventive effect of Euphorbium com. is higher against BVDV-1, though the difference is insignificant. Such effect implies interferon-inducing activity, which according to Enbergs (2006) does not depend on the dose. Both viruses are highly sensitive to cattle interferon (Fulton et al., 1986), and their replication in the body can be influenced by interferon inductors.

It seemed particularly important to study the in vivo antiviral activity of the homeopathic remedies to confirm the in vitro results. In the experiment, acute viral infection was simulated by intranasal administration of live attenuated strains of the BHV-1 and BVDV-1 viruses to seronegative calves. To carry out this experiment, we chose Engystol, for which we had already established a preventive effect. This remedy was available in a formulation for injection. The remedy was administered in the recommended doses (Lypin, 1997).

Our studies found that Engystol plays a role in the decrease of the concentration of the viruses and the duration of their excretion with the calves' nasal discharge. In the test group compared to control, the titres of BHV-1 were lower by 1.94-3.40 $\log _{10} \mathrm{TCID}_{50 / \mathrm{mL}}$ and the titres of BVDV-1 were lower by $0.14-3.28 \log _{10} \mathrm{TCID}_{50} / \mathrm{mL}$. Only on the next day after the inoculation, the titre of BHV-1 in the test group was higher than in the control group by
$0.46 \log _{10} \mathrm{TCID}_{50} / \mathrm{mL}$. On day 14 after the inoculation, the titres of $\mathrm{BHV}-1$ and BVDV-1 in the control group were $3.25 \pm 0.14 \log _{10}$ TCID $_{50} / \mathrm{mL}$ and $2.75 \pm 0.10$ $\log _{10} \mathrm{TCID}_{50} / \mathrm{mL}$ respectively, whereas in nasal discharge of the test animals the viruses were undetectable. The remedy had no effect on the level of antiviral antibodies. The difference between the study and control groups was insignificant $(\mathrm{P}>0.05)$.

Live attenuated strains of BHV-1 and BVDV-1 replicate in the same body cells as virulent strains, but the former are produced in lower titres and are eliminated from the body faster. According to our data, Engystol may have a therapeutic activity during outbreaks caused by these viruses, but the dose, frequency and duration of its administration must be established in further studies.

\section{CONCLUSIONS}

This study found that the tested combination homeopathic remedies have an in vitro and in vivo antiviral activity against the BHV-1 and BVDV-1 viruses. However, further randomised studies involving large populations of animals are required to find out if these remedies can be used for treatment of infections in cattle caused by these viruses.

We believe that the observed in vivo effects of Engystol can be explained by its interferon-inducing activity, rather than by a direct antiviral action.

\section{REFERENCES}

Anetzhofer, J., 1993. Echinacea compositum ad us. vet. in der therapie von infektionskrankheiten. Biologische Tiermedizin, 10, 46-60. 
Brogden, K. A. \& J. M. Guthmiller, 2002. Polymicrobial Diseases. ASM Press, Washington.

Clausena, J., H. Albrechta \& R. T. Mathieb, 2013. Veterinary Clinical Research Database for Homeopathy: Placebo-controlled trials. Complementary Therapies in Medicine, 21, 115-120.

Danilov, L. L., S. D. Maltsev, A. V. Deyeva, A. N. Narovlyansky, A. V. Sanin, S. V. Ozherelkov \& A. V. Pronin, 1996. Phosprenyl: A novel drug with antiviral and immunomodulatory activity. Archivum Immunologiae et Therapiae Experimentalis, 44, 395-400.

Enbergs, H., 2006. Effects of the homeopathic preparation Engystol on interferon-gamma production by human T-lymphocytes. Immunological Investigations, 35, 19-27.

Fulton, R. W., L. J. Burge \& L .J. McCracken, 1986. Effect of recombinant DNA-derived bovine and human interferons on replication of bovine herpesvirus-1, parainfluenza-3, and respiratory syncytial viruses. American Journal of Veterinary Research, 47, 751-753.

Glatthaar-Saalmüller, B. \& P. Fallier-Becker, 2001. Antiviral action of Euphorbium compositum and its components. Forschende Komplementirmedizin und klassische Naturheilkunde, 8, 207-212.

Glotov, A. G., O. G. Petrova, T. I. Glotova, A. V. Nefedchenko, A. T. Tatarchuk, S. V. Koteneva, G .K. Vetrov \& A. N. Sergeev, 2002. Diffusion of virus respiratory diseases of cattle. Veterinaria, 3, 17-21 (RU).

Glotov, A. G., T. I. Glotova, A. A. Sergeev \& A. N. Sergeev, 2004. Study of antiviral activity of different drugs against bovine herpes virus and pestivirus. Antibiotiki $i$ Khimioterapija, 49, 6-9 (RU).

Glotov, A. G., T. I. Glotova \& O. V. Semenova, 2013. Manifestation of infectious bovine rhinotracheitis in calves early age. Veterinaria, 12, 88-92 (RU).

Grandel, E., 1976. Die Behandlung der Rindergrippe (respiratorische und enteritische Verlaufsform) unter besonderer Berücksi- chtigung von Viruvetsan. Tierärztliche Umschau, 31, 551-556.

Griffin, D., 1997. Economic impact associated with respiratory disease in beef cattle. Veterinary Clinics of North America. Food Animal Practice, 13, 367-377.

Habriev, R. U., 2005. Management on Experimental (Preclinical) Studying of New Pharmacological Substances, 2 edn, Publishing House Medicine, Moscow (RU).

HEEL, 2003. Veterinary Guide. 3rd English edn, Biologische Heilmittel Heel GmbH.

Kaiser D., 1989. Wiederentdeckt: ein grundlegendes Manuskript Hahnemanns. Zeitschrift für klassische Homeopathie und Arzneipotenzierung, 33, 112-120.

Kinchington, D. \& R. F. Schinazi, 2000. Antiviral Methods and Protocols. Humana Press Inc., New York.

Kovacs, C. \& I. Gubanowa, 2000. Biologische Behandlung von Atemwegs- und MagenDarm-Infektionen bei Jungrindern. Biologische Tiermedizin, 17, 59-62.

Lypin, A. V., 1997. Veterinary Practical Work of Homotoxicology, Gotika, Moscau (RU) .

Oberbaum, M., B. Glatthaar-Saalmüller, P. Stolt \& M. Weiser, 2005. Antiviral activity of Engystol: An in vitro analysis. Journal of Alternative and Complementary Medicine, 11, 855-862.

OIE, 2000a. Bovine viral diarrhoea. Chapter 2.4.8. In: Manual of Standards Diagnostic Tests and Vaccines, $4^{\text {th }}$ edn, Office International des Epizooties.

OIE, 2000b. Infectious bovine rhinotracheitis/ infectious pustular vulvovaginitis. Chapter 2.3.5. Manual of Standards Diagnostic Tests and Vaccines, $4^{\text {th }}$ edn, Office International des Epizooties.

Pronin, A. V., E. A. Grigorieva, A. V. Sanin, A. N. Narovlyansky, S. V. Ozherelkov, A. V. Deyeva, L. L. Danilov, S. D. Maltsev \& A. Najid, 2002. Polyprenols as possible factors that determine an instructive role of the innate immunity in the acquired immune response. Russian Journal of Immunology, 7, 135-142 (RU). 
In vitro and in vivo activity of homeopathic drugs against bovine herpesvirus-1 and bovine viral ....

Reed, L. J. \& H. Muench, 1938. A simple method of estimating fifty percent endpoints. American Journal of Hygiene, 27, 493-497.

Roeska, K. \& B. Seilheimer, 2010. Antiviral activity of Engystol ${ }^{\circledR}$ and Gripp-Heel ${ }^{\circledR}$ : An in-vitro assessment. Journal of Immune Based Therapies and Vaccines, 8, 6-14.

Schmolz, M. \& H. Metelmann, 1998. Modulation of cytokine synthesis in human leukocytes by individual components of a combination homeopathic nasal spray. Biologische Medizin, 8, 155-158.

Taylor, J. D., R. W. Fulton, T. W. Lehenbauer, D. L. Step \& A. W. Confer, 2010. The epidemiology of bovine respiratory disease: What is the evidence for predispos- ing factors? Canadian Veterinary Journal, 51, 1095-1102.

Paper received 20.07.2014; accepted for publication 02.10.2014

\section{Correspondence:}

Alexey Nefedchenko

Institute of Experimental Veterinary Medicine of Siberia and Far East

630501 Novosibirsk area,

r.p. Krasnoobsk, a/ja 8

Russian Federation

phone/fax: 007-383-308-77-45

e-mail: homeovet@yandex.ru 